\title{
EFFECTIVENESS OF FOLLOW-UP ON PERFORMANCE AUDITING ISSUES IN PRACTICE: A GOVERNANCE NETWORK PERSPECTIVE
}

\author{
SARIMAH UMOR 1,2 \\ ZARINA ZAKARIA ${ }^{2}$ \\ NOOR ADWA SULAIMAN2,*
}

Received: 12 December 2018 / Revised: 13 February, 13 May 2019 / Accepted: 16 May 2019 (C) 2020 Faculty of Business and Accountancy, University of Malaya. All rights reserved.

\begin{abstract}
A B S T RACT
Research aim: This study discloses the relationship between governance arrangements and network types (networking) and the effectiveness of follow-up practice.

Design/ Methodology/ Approach: Governance network theory (GNT) was utilised together with the interpretative phenomenological approach. Fifty-five governance actors in the Malaysian public sector that consist of the auditors, auditees, regulators and other relevant actors were divided into four groups. Their stories and experiences collected via interviews constitute the main data for this study.

Research finding: This study noted three phases of follow-up strategies which are pre; during; and post-tabling of the Auditor-General's (AG) report in Parliament. This follow-up practice involves a new way of governing with the involvement of many actors. It is not limited to auditors and auditees. Data from this study evidenced that networking approaches based on three types of network, namely coordinative, cooperative and collaborative, have enhanced follow-up practice as evident in the dissemination of punitive audit issues to the right actors for further action.

Theoretical contribution/ Originality: This research has provided evidence that study of followup on performance audit issues in practice encapsulates social behaviour, societal governance, and network perspective and produces stimulating results.

Practitioner/ Policy implication: Supreme Audit Institution (SAI) must find a way to reduce the hierarchical nature of its work by entrenching its strategy, structure and process to ease governance arrangements and networking between various actors outside the SAI organisation in resolving the audit issues raised in the AG report through effective follow-up practice.

Research limitation/ Implication: The researcher did not select performance auditing issues individually per se to see how each issue with punitive elements is addressed through a followup process. In order to perform in-depth research, researchers should select punitive issues and execute case study research.
\end{abstract}

Type of article: Research paper

Keywords: Performance Auditing, Follow-Up Practice, Governance Arrangement, Networking, Governance Network

JEL Classification: M42, M48, H83, H77

\section{Introduction}

Performance auditing in the public sector has become one of the most important responsibilities of the auditors, especially government auditors in Malaysia,

\footnotetext{
${ }^{1}$ National Audit Department of Malaysia, 62518 Putrajaya, Malaysia

${ }^{2}$ Faculty of Business and Accountancy, University of Malaya, 50603 Kuala Lumpur, Malaysia

* E-mail for corresponding author: adwa@um.edu.my
} 
besides their traditional role responsibilities with regard to financial audit. In Malaysia, the role is entrusted to the National Audit Department of Malaysia (MNAD) which is headed by the Auditor-General. The MNAD is better known as an institution tasked with ensuring accountability because its primary function is to call public officials to account (Mulgan, 2000). It plays a key role in ensuring public accountability with a mandate from Articles 105-107 of the Constitution of Malaysia, and Audit Act 1957. Performance auditing is a means to achieve not only efficiency, economy and effectiveness, but also to contribute towards improving performance (Alwardat, 2010; Barrett, 2012; Morin, 2014), public policy (Reichborn-Kjennerud, 2014), and public services (Arthur, Rydland, \& Amundsen, 2012).

However, Siddiquee $(2014,2013,2010)$ found that among the reasons for dissatisfaction with public service performance are inefficiency and waste within the government, poor implementation of development policies and programmes, and weak financial management. According to the author, the issues of inefficiency and ineffectiveness have been continuously highlighted in the AG report on performance auditing and publicised through mass media due to repetitive cases of corruption among public actors (Siddiquee, 2010). This is intensified by the emergence of high-profile cases in Malaysia such as 1Malaysian Development Berhad (1MDB), National Feedlot Corporation (NFCorp), Federal Land Development Authority (Felda), and Port Klang Free Zone (PKFZ) that have driven the public to question the governance and effectiveness of the follow-up on the performance auditing issues raised.

The follow-up aspect has, to date, received little attention in the literature. Studies have found that the importance of follow-up arises from the real value and impact on performance auditing activity (Morin, 2014). Research on the impact and value of performance auditing on public sector organisations (Bawole \& Ibrahim, 2015; Raudla, Taro, Agu, \& Douglas, 2015) has been a leading field of inquiry in recent years. Whether performance auditing has an impact on the improvement of auditee entities (Yang, 2012), its usefulness in the eyes of auditees (Reichborn-Kjennerud, 2015), the consequences of performance auditing (Reichborn-Kjennerud \& Vabo, 2017), overall impact of performance auditing as a result of the implementation of audit recommendations (Hoque \& Pearson, 2018), changes it brings in the audited organisations (Morin, 2014), and the contributing factors for those changes (Siddiquee, 2014), still merit further research from the aspect of follow-up on performance auditing issues. Therefore, in ascertaining follow-up effectiveness, one must also consider the practices by which it is being governed.

Follow-up on performance auditing issues was initiated to track the implementation of audit recommendations that are directed towards action. The International Standard for Supreme Audit Institution (ISSAI) 3000 regarded the objectives of follow-up as helping to augment the effectiveness of the audit report; assist legislature; evaluate the SAI performance and provide input to enhance policy with regard to performance auditing in the public sector (ISSAI, 3000, 5.5). The importance of follow-up on the AG's report has become a leading priority of the government as stipulated in the GTP roadmap "high-powered task force headed by Chief Secretary General to the Government (KSN), to study the... Auditor-General's 
report and take action against those responsible for the financial irregularities it revealed" (p. 128). "The setting up of a high-powered task force headed by the KSN to study and take action based on the year 2008 Auditor-General's report is indicative of our stance in this" (p. 134) (GTP Roadmap, 2010). By considering the potential benefits of follow-up in embracing the real value and impact of performance auditing, the MNAD initiated and championed the changes related to follow-up practice. Even though numerous transformation programmes have been initiated, there is limited information about reform initiatives and its effectiveness (Siddiquee, 2014; Xavier, Siddiquee \& Mohamed, 2016).

Furthermore, follow-up on performance auditing issues has neglected the exploration of how the practice is being governed, or explored the impact of performance auditing activity and its association with the implementation of audit recommendations which are mostly from the auditee's perspective (Morin, 2014, 2015). From the auditor's perspective, studies have found that auditors alone could not compel or force the auditees to act on the audit issues and adopt audit recommendations. For instance, Kells and Hodge (2011) reveal that the reasons lie in lack of the auditors' power to take action on auditee resistance and unsupportive attitudes (Reichborn-Kjennerud, 2015, 2014).

Due to this reason, recent literature claimed that the effectiveness of follow-up practice can also be improved by governing the practice and involving many other actors which is not limited to auditors or auditees alone. The actors that could exert influence on follow-up practice are the Parliament (Morin, 2014), Public Account Committee (PAC) (Bringselius, 2014), media (Pehe, 2012), and citizens (Bhandari, 2014; Yapa, 2014). In order to enhance follow-up effectiveness in the performance auditing activities, particularly in resolving or tackling performance auditing issues, it is essential to understand the actors involved and how they form a relationship and interact within a network. These are the aspects that this paper has explored and provides a timely viewpoint from four groups of actors, namely the auditors, auditees, regulators and other relevant actors alike. By highlighting the state-of-the-art of current follow-up practice within performance auditing which involves the interaction between various actors, this paper provides a greater understanding of this under-researched area.

Interaction between actors within a network in the current follow-up practice is explored through a governance network theory (GNT). Governance network theory is a consequence of the interaction between various actors and governance arrangement (Kooiman, 2003, 1993). Meanwhile, although network types (networking) are not a core concept of governance network theory as pointed out by Klijn and Koppenjan (2012), the authors' claim, in governing social practice, the important aspect is how the network is managed.

Therefore, governance network can be a conclusive theory to provide an indepth understanding of how follow-up is practised through governance network arrangements and networking between various actors. This theory is used to capture the understanding of the relationship (governing and networking) between interacting actors that contributes to the effectiveness of follow-up practice. The effectiveness of follow-up practice lies predominantly in the initiatives and changes made to the practice (interaction between various actors) under the government transformation programme (see Government 
Transformation Programme 2). This exploratory study examines the influence of governance arrangement and networking (network types) on the effectiveness of follow-up practice.

The remainder of this paper is organised as follows. Section 2 reviews and summarises the literature and publications in the field of public sector performance auditing that triggered the rise and the current need of follow-up practice. Section 3 describes the methodology of the study. Section 4 provides findings and discussions of this qualitative study. Section 5 concludes the paper with a summary, limitations, implications and avenues for future research.

\section{Literature Review}

Following-up on performance auditing issues has undergone limitedly study and evinced little attention in the literature. Follow-up on performance auditing issues raised in the Auditor-General's (AG) report is to track the implementation of audit recommendation. The International Standard for Supreme Audit Institution (ISSAI 3000) termed the objectives of follow-up which help augment the effectiveness of the audit report, assist legislature, evaluate the SAI's performance and provide input to enhance policy with regard to performance auditing in the public sector. However, this practice has not been explored directly. Moreover, evidence presented thus far supports the idea that little is known about the impact of AG's performance auditing report. Morin (2014) argues that: "one can only hope that the parliamentarians who examine the AG's reports ask the right questions and exert sufficient pressure on the administration to ensure a proper follow-up to the AG's performance auditing findings. Blind faith may come into play: faith that parliamentarians have the sustained will and efficiency to control the executive, notably through the work of AG. This assertion is far from proven" (p. 396), and left unanswered empirically.

The above gap arises from the process by which, since the wake of the report, has been monitored by various parties concerned namely the AG representing the SAI, the auditors, PAC inquiry session, media sensational comment to mostly publically interested topics, the ministry level, management of audited organisations, and the general public. As cited by Brooks and Pariser (1995), "auditors to communicate their findings and provide recommendations that may improve government operations and programmes" (p.1). The real benefit of auditing comes from the implementation of audit recommendations that results in improvements in government operations. According to the authors, public sector managers, analysts, and officials at all levels of government must follow-up (monitor) on audit recommendations to ensure their effective implementation (ReichbornKjennerud, 2015). Studies demonstrate that, challenges surrounding follow-up on performance auditing could be many, but the ones mostly debated are repetitive performance auditing issues due to the lack of implementation of audit recommendations. Pressures with regards to the implementation of audit recommendations implementation are influenced by factors such as auditees' acceptance and the effectiveness of audit recommendations as accountability mechanisms for performance improvement (Mzenzi \& Gaspar, 2015).

The authors suggest the SAI auditors to enhance accountability when the scope is widened to provide relevant information and when audit recommendations are implemented by auditees. However, in their concluding remarks, using agency 
theory as the basis, these authors stress that the SAI auditors have not sufficiently ensured the stakeholders to hold auditees accountable. This means, in order to resolve shortcomings in the implementation of audit recommendations, follow-up may help when the auditees are aware that this practice will take place (Reed \& Mars, 2014). Therefore, the auditees will most likely not only take corrective action but preventive action as well.

Alwardat, Benamraoui, and Rieple (2015) used role theory and audit expectation gap theory to examine auditors' and auditees' expectations and perceptions. A common agreement between auditors and auditees is the impact of performance auditing which can be derived if audit recommendations suggested by auditors are implemented by auditees. This is considered as the key part of performance review. The main finding of this trio authors are, despite the fact that performance auditing can improve institutional performance in the public sector, auditors and auditees have differences in their expectations and perceptions about each other's role and contribution which then give rise to significant role conflict. Therefore, the issue of implementation of audit recommendations which is disputed continuously between auditors and auditees should be examined in-depth to identify the factors affecting such disagreement and dissatisfaction among them. In addition, the dispute should be seen from the aspect of interaction that is not limited to auditors and auditees, but include all the relevant actors. Therefore, how follow-up practice occurs to resolve audit issues by various actors as well as challenges that surround the practice are still not fully explored and disclosed.

Various actors' role in following-up on performance auditing issues has bot been subject to significant research because researchers have been met with limited accessibility to capture all the actors concerned in one study (Irawan \& Mills, 2016), focus on the internal audit context (Ahmad, Othman, \& Jusoff, 2009; Mihret \& Yismaw, 2007) and performed research restricted to auditor-auditee perspectives (Funnell \& Wade, 2012). The 'impact' of performance auditing literature can be inferred based on the implementation of audit recommendations (Morin, 2014; Kells \& Hodge, 2011). According to Alwardat (2010), 'impact' of performance auditing mostly focuses on both auditors' and auditees' perspectives, thus paying less attention to other actors' roles. For example, according to Irawan and Mills (2016), other stakeholders that need to be considered are media, professional bodies and key government agencies such as the government evaluation agencies. While in the context of this study, the role of enforcement and central agencies seems inevitable.

The relationship between actors is an important depiction of an early sign of networking in the public auditing. For instance, a longstanding researcher has demonstrated that performance auditing has the potential to reinforce the accountability relationship between public sector entities and the general public (Lonsdale, 2008). Such a relationship is formed beyond the common auditorauditee relationship. In particular, media was claimed as one of the actors that exist within such a relationship. In this respect, Stamati, Papadopoulos, and Anagnostopoulos (2015) demonstrate the influence that media could impose by publicising AG's reports concerning government use of public funds. According to the authors, media openness and transparency in the public sector could 
expedite the dissemination of information between the government and the citizens. Some researchers highlight that the interaction between SAI's auditors and auditees, and the ability to satisfy the Public Account Committee (PAC) could also contribute towards the effectiveness of follow-up practice (ReichbornKjennerud, 2014). This could be the reason for McGee and Gaventa (2011) to claim that government accountability and transparency are "active with rapidly emerging citizen led and multi-stakeholder initiatives" (p. 5). It means that the formation of the relationship between actors in following-up on performance auditing issues is not limited to auditors and auditees. For this reason, the governance network theory is used due to its relevance to current research and considering the New Public Governance (NPG) paradigm whereby multiple actors are involved in the public administration service (Osborne, 2006).

Governance network theory is based on the assumptions that reality of interaction is based on what forms an actor's role, interdependence, frames, interaction complexity, institutional feature and network management (Klijn \& Koppenjan, 2012). For instance, interaction entails socially agreed-upon ideas of the world and social patterns and rules of language use. Constructions of social meanings, therefore, involve diverse perspectives among actors. Hence the diverse perspective (intersubjective) that exists between four groups of actors are expected to be explained by the adoption of governance network theory. With this in mind, this research uses governance network theory as a foundation to understand the governance arrangement and networking relationship process. The reason is that governance network offers a concise theoretical lens to understand the interaction process between auditors, auditees, regulators and other actors. Consequently, we explore how this interaction process can influence the effectiveness of the follow-up practice.

There is also limited understanding about how auditors' interaction with other actors such as regulators and related actors influences their views of follow-up practice and vice versa. There has been little attention given as to how the actors' views of the nature of follow-up practice are constructed, represented and reacted to by auditors, auditees, regulators and other relevant actors within a network perspective and consequently the way this practice is governed. For this reason, the use of governance network theory which is rooted in institutional theory of new institutionalism is deemed appropriate (Klijn \& Koppenjan, 2000, 2012; Sørensen \& Torfing, 2007). Governance network theory has received limited attention thus far in the field of performance auditing. It is emerging as an important theory in today's complex and challenging public sector environment that is surrounded with the issues of governing and networking due to various actors' interaction. This study attempts to add to research findings and knowledge of the issues.

The idea of governance as network practices was propagated by Rhodes (1996). Later, Sørensen and Torfing (2005) presented some positive points for prompting research from a governance network perspective. Scholars have used different definitions to grasp the meaning of governance network such as governance networks (Klijn 2008; Torfing 2006; Klijn \& Koopenjan, 2000), collaborative governance (Vangen, Hayes \& Cornforth, 2015; Emerson, Nabtchi \& Balogh, 2012), and complex governance network (Morçöl, 2014). Governance in this sense is a 
kind of arrangement that denotes a distinct type of governance to prevent confusion with other usages of governance. Thus, in the context of this research, governance network is regarded as interdependency and the dynamics of modern public strategy (Sullivan, Williams, Marchington, \& Knight, 2013; Sørensen \& Torfing, 2011; Klijn \& Koppenjan 2012). Based on different definitions, the terms 'network governance' and 'governance networks' have been used interchangeably. Network governance can be seen as the type of governance that is realised through networks, while governance networks can be seen as the networks that are established as part of a governance arrangement. The 'governance arrangements' are conceptualised as a governing process by means of the relationship of interdependent, but operationally autonomous actors who interact and negotiate to achieve public outcomes (Sørensen \& Torfing, 2007; Torfing, 2005). Sørensen and Torfing (2007) specify governance network theory as actor interdependencies or frames, interaction complexity, and institutional features for institutionalisation of relationship between actors and network management. Thus, these authors assert that public issues solved from governance arrangements are as a result of negotiated interaction between interdependent and operationally autonomous actors.

For the purpose of networking, network types that meet various goals and purposes are needed (Keast, Brown, \& Mandell, 2007). These authors assert that, although networks share common characteristics, they vary in terms of structural arrangements such as relational strengths, integration mechanisms, and strategies (Keast \& Mandell, 2013). This study adapts networking based on network types as the underlying lens to explain the relationship based on process and structure that encompasses of three network typologies (types) which are cooperative, coordinative, and collaborative (Keast et al., 2007). Keast and Mandell (2013) further describe the network typology structure (relationship) and the process involved. Cooperative network formed on a short-term basis is informal and executed with the intention to share information between interacting actors within the same organisation or from different organisations. Coordination supports the formation of relationships between interacting actors with the aim to organise or arrange people, tasks, and resources to achieve a determined goal with better coordination. The process during the formation of relationship exceeds and goes beyond information sharing. A collaborative network is formed by reciprocal interdependence between interacting actors. It means the actors mutually understand that their collective effort is needed to solve problems rather than a single actor's effort, role or action. The authors further assert that for information sharing and mutual adjustment, a cooperative network is deemed appropriate.

For better coordination and mutual goals, cooperative and coordinative networks focus are deemed appropriate because they can make only small changes in interactions and activities. Finally, collaborative network is more tightly linked and demands stronger relational commitment, and goals. Based on the above description and arguments, a precondition in influencing the effectiveness of follow-up practice might be achieved, given that the conditions in relation to governance arrangements (strategy) and networking (structure and process) are met. The study has positioned governance arrangements (strategy) and networking (network typology based on structure and process) as a primary 
construct in understanding follow-up practice. Relationship is manifested between governance arrangements and network typology on the follow-up effectiveness. This new framework shows the conceptual links between the two constructs. The exploration of the relationship facilitates a clearer understanding about the impact of the constructs on follow-up effectiveness, as illustrated in Figure 1.

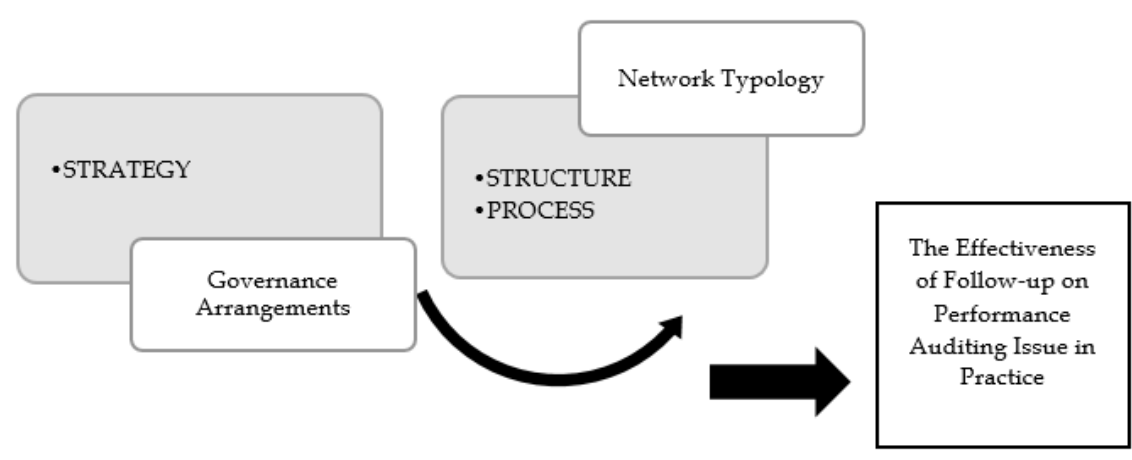

Figure 1: Conceptual Framework

\section{Methodology}

This study adopts a qualitative research design that is framed in terms of using words that answer emerging questions which focus on individual meanings and the importance of depicting the complexity of a status quo (Creswell, 2014) for generating reliable and insightful social research (Denzin \& Lincoln, 2011).

It collects data from interviewees' objectivity, truthfulness, believability, coherence, insight and trustworthiness (Creswell, 2014). On such a continuum, the objective of this qualitative research methodology does not aim to make generalisations and stretch solid inferences about the aforementioned issue. Instead, it is an alternative attempt to reveal its effectiveness.

Studies on performance auditing particularly in the context of follow-up for the past five years are mainly based on large samples, utilise questionnaires to collect data (Morin, 2014) and rarely attempt to give in-depth insights into the interaction involving diverse actors. Thus, the governance arrangement (process) and networking (relationship) cannot be sufficiently explored using survey through questionnaires or even secondary data available in the Auditor-General's report. This is because the interaction among diverse actors (not limited to auditors and auditees' perspective) is difficult to capture if quantitative method is used. By understanding how governance arrangement and networking may contribute to the comprehension of follow-up practice and its process, qualitative research provides the researcher with a path to capture the subjective perspectives of key network actors in order to gather richer information.

Through the field studies of actual network phenomena, the researcher is able to discover the underlying structure of shared essences of some social phenomena. Therefore, the core philosophical assumptions based on subjectivist ontology opted, assert that reality is based on an individual actor's consciousness, shared meanings and conceptions through human interactions and relationships. 
Considering that the belief of social constructivism epistemology is closely related to interpretivism, this paper regarded shared meanings and understanding concerned with knowledge as produced and interpreted. In the context of this paper, each individual actor constructs his knowledge within the social-cultural context influenced by his prior knowledge and understanding.

The study adopts an interpretive research paradigm in line with the current phenomenology research strategy. It delves into the subject matter to discover and identify how the phenomenon was experienced. The experiences of different people are bracketed, analysed, and compared to identify the essences of the phenomenon, for example, the essence of governance arrangement and networking on follow up effectiveness. In this sense, the assumption of the essence is directed to the basic structure of experience.

The phenomenology interpretive research favours the use of in-depth interview as it paves the way to an in-depth enquiry into human behaviour. Indepth enquiry is capable of generating significant insights into the core social concepts of the research questions. As such, several steps were taken to collect data. The actual data collection approach was executed through snowball sampling of actors from the public sector audit environment.

Interviews undertaken with auditors from the National Audit Department were introduced to a wide network of other actors involved directly or indirectly in follow-up practice. The actors are not limited to auditors and auditees, but include regulators such as Parliament Members/Public Account Committee (PAC), Malaysian Anti-Corruption Agency (MACC), Royal Malaysian Police (Police), Attorney General's Chamber (AGC), Public Service Department, Representative of Chief Secretary General Office (KSN Office), Legal Officer/Adviser, Internal Audit Unit, Integrity Unit and a few media representatives. Media representatives were also interviewed following the interviews with auditors and auditees. The researcher then realised that media could also exert an indirect influence on follow-up practice. Further, justification for the number of interviewees is based on Patton (2002, p. 244) who claims that "...there are no rules for sample size in qualitative inquiry. Sample size depends on what the researcher wants to know, the purpose of the inquiry, what's at stake, what will be useful, what will have credibility, and what can be done with available time and resources".

It was determined that all research participants involved in the follow-up practice have solid experience and relevant background of knowledge in order to form a defined group as presented in Table 1 that is significant for the study objectives. An interview guide was prepared after going through a careful and systematic process. The semi-structured interview guide revolves around five (5) major themes which were the individual role played in the follow-up work process, nature and extent of interaction, level of involvement, approach used to form a relationship with other actors, process and their view about the practice and their anticipation. The questions that were posed to auditors, auditees, regulators and other actors sought to understand the extent to which the actors are involved in and play their role to ensure the effectiveness of follow-up practice. Most importantly, the purpose of the questions regarding the interaction among actors is to determine how well the actors play their role in tackling audit issues and work out for settlement. 
Table 1. Summary of the Four Groups of Interviewees

\begin{tabular}{lccc}
\hline Actors & No. & Category & No. Grouped Into \\
\hline Auditor & 14 & Auditors & Auditors (14) \\
Auditees & 11 & Auditees & Auditees (11) \\
Public Service Department (JPA) & 1 & Administrator & \\
$\begin{array}{l}\text { Office of Chief Secretary General } \\
\text { to the Government of Malaysia }\end{array}$ & 1 & Administrator & \\
(KSN Office) & 3 & Oversight & Regulators (15) \\
Ministry of Finance (MOF) & 4 & PAC & \\
PAC/Parliament Members & 4 & Enforcement Agency & \\
MACC (Anti-Corruption Agency) & 1 & Judicial & \\
AGC (Attorney General & 4 & Enforcement Agency & \\
Chambers) & 1 & Media & \\
RMP (Police) & 4 & Internal & \\
Media & 6 & Control/Coordinator & \\
Internal Auditors & 2 & Coordinator & Other Actors (15) \\
Integrity Unit & 1 & Advisory & \\
Legal Officer & 2 & Public/Political Actors & \\
Influential Public (Former & & & \\
Government Leader/Public & 55 & & \\
Official) & & & \\
Total & & &
\end{tabular}

The interview questions are designed to make it possible for the interviewees to reveal their experience about the phenomenon. Data were gathered through indepth face to face interviews. The interviews lasted from 29 to 169 minutes. All interviews were fully recorded after getting the interviewees' consent. On the basis of audio recordings and note taking, audiotape recordings were transcribed typically between 10 and 24 pages in length. These could also be the reason why some of the reports sent to the interviewees for approval were returned without any changes. Almost all interviewees refused to review the transcribed report or did not use this opportunity to suggest any changes to the interview reports or make additional remarks.

Further, this particular study employed Atlas.Ti, as this software package is widely used. However, the function of this software is mainly to manage the fairly huge number of data from the interview that involves 55 interviewees. This is in line with the claims made by longstanding literature that the software package is only used to organise large volumes of data and not to develop strategy to formulate the analysis (Myers, 2013). Thus, data familiarisation using Atlas.Ti aims mainly to get closeness to data and interactivity, data exploration, code and retrieval functions, and data organisation, and to search and interrogate the database for further analysis.

Thematic analysis was used to analyse the interview data managed through the above software. Braun, Clarke, and Terry (2019) explain the manner in which such analysis can be conducted. In defining and naming themes, this phase started by mapping the data into the thematic map. Detailed analyses for each theme were conducted in order for the researcher to fit them into the broader overall story of effectiveness of follow-up in practice. For this reason, the data analysis for the current research started with data familiarisation in stage 1. 
Data familiarisation in the context of this research used software assistance and is regarded as an analytical process, particularly for data management. In stage 2, the researcher referred to the research questions to determine precisely the coding process. Next, in stage 3, the labels and codes marked from large data sets with rich information were reviewed. All of the codes need to be revised individually to avoid redundancy. Thus, important processes such as comparison and contrast of heading and subheading to represent themes and subthemes have been undertaken.

In stage 4 , once the coding process and grouping of codes under certain labels were completed, data were then analysed to identify the suitability of the potential themes derived from the data in line with the research questions.

Only after this process has been completed in stage 5 were the themes classified according to broader themes that are more specific and compiled based on the general lens of the theory used in this study. As suggested by Braun and Clarke (2006), themes and subthemes provided from the data must be related to the research questions as it is useful to have a structure in order to understand a large and complex story and the meanings within the data.

It is important to note that although common themes and subthemes were established from the interviewees' answers, each expression was unique and distinctive as a social constructivism of reality (Berger \& Luckmann, 1967). In the last phase of stage 6, a rigorous thematic approach was taken to analyse data and produce an analysis of the findings. It involves the careful act of merging together the analytical narrative and data extracts in order to contextualise the analysis so that it related to the research questions and the broader theoretical assumptions of this paper.

\section{Empirical Qualitative Analysis}

\subsection{Governance Arrangement (Strategy)}

To understand governance arrangements in the follow-up practice, an understanding of the important strategy (events) that takes place through various actors role and involvement before and after the $\mathrm{AG}^{\prime}$ 's report is tabled in Parliament are explored. Governance arrangements through various actors' involvement appear apparent because the actors have a clear understanding of how their roles are linked to the roles of others, and vice versa. This depicts that the actors' roles are essential in maintaining governance arrangements at optimum level across follow-up practice. For example, Auditor 9, Regulator 6 and Other Actor 12 describe:

"In line with the follow-up initiatives, even before the tabling of AG report, we share information about particular issue to many parties such as enforcement agencies. This even takes place during the exit conference meeting" (AUDITOR 9)

"We attend the exit conference meeting to follow-up on the issues that will be raised in the AG report. We are the representative from Ministry of Finance (MOF)" (REGULATOR 6-MOF). 
"Usually, after the auditing undertaken by the MNAD team, they will issue an audit observation. Later there will be an exit conference. But beforehand they will give auditees time to prepare feedback answers. So, in the exit conference they will discuss on the issue as well as the feedback answers" (OTHER ACTOR 12).

Hertting (2003) defines and describes how interdependency between various actors is interpreted as an incentive strategy for governance network formation. In this respect, the interviewed participants acknowledged the existence of this form of interconnectedness as interdependency. This interconnectedness is fostered through important events during the tabling of AG's report and with major events after the tabling of $\mathrm{AG}^{\prime}$ s report.

"Because once are you been audited and if there are issues raised in the AG report, the process will be long. It was really like a very long process with so many meetings, discussion, brainstorming, exit conference, town hall, PAC and finally the Action Committee of the Auditor-General Report (JTLKAN) meeting and this I can say most important one. Furthermore, at the same time we need to continuously follow-up through AG Dashboard" (AUDITEE 4).

Actors' view of the world is most likely influenced by their understanding of constructed reality of a particular phenomenon. Thus, they tend to choose strategies based on their perception (or frames) of the world (Klijn \& Koppenjan, 2012). Based on the interviewees' explanation with regards to the number of strategies initiated to follow-up on issues raised in the report, it is framed punitively and correctively. The corrective issues listed in the AG's Dashboard will be jointly followed-up by auditors and auditees on a continuous basis until completion. It means, the nature and extent of the relationship at this level, based on the interviewees' description, involves interactions between auditors and auditees.

"AG Dashboard is very useful and keeps reminding us by online notification to update on action taken, particularly on the corrective issues and we will communicate continuously with auditors from Follow-up Division (FUD). Whatever within our capacity we will take action and update here" (AUDITEE 5)

"We will follow-up on corrective issues on continuous basis through AG Dashboard. After the AG report tabled in Parliament and within one month's times, auditees will update the status of action, I mean until complete" (AUDITOR 8).

In an environment where interdependency between actors who have a variety of perception and strategies such as complex interaction and negotiating patterns, resolving issues and problem-solving may require interactions of many actors rather than of the action of one single actor (Klijn \& Koppenjan, 2012). Actors engage in horizontal relationships and interact. These according to the interviewees, are highly encouraged by complexity with regard to the issues that need to be resolved in networks. The interviewees tended to view it as essentially a matter of strategies executed along the process. For instance, firstly the PAC 
Briefing session. The PAC will select certain issues (usually involve public interest and benefit such as housing, education, transportation and so on) for further inquiry through PAC Proceedings.

"When we get a report that presented by AG in Parliament. During the PAC Briefing session, we will choose few issues for further inquiry (PAC Proceeding). We focus on matters that relates to public interest like public transport or housing" (REGULATOR 1-PAC).

Next, after the AG's report is tabled in Parliament (post), the interaction becomes more extensive and the sign of networking seems apparent. All punitive issues with elements such as disciplinary, corruption and crime as classified by the Follow-up Division at the MNAD will be used in the follow-up process involving various actors.

"The initial audit team only produce the report and Follow-up Division will take over the follow-up matters. Further communication with external parties is through us. We need to complete the notification paper and for that reason we will do some extended investigation on the punitive issues that we have classified earlier" (AUDITOR 11).

Further, for punitive issues that involve any ministry, the Public Service Department (PSD) will set up an Investigation Committee at the ministry's level, headed by the Integrity Unit. Members of the committee are elected from the department other than the department being investigated within the ministry. The result from the Investigation Committee will be used during a town hall session with the media organised by the KSN office in collaboration with the PSD. It means, the current status of the punitive issues will be presented in an interactive manner with the media. Those present during the session include the auditors, auditees, other actors and regulators from central agencies like the PSD and representative from KSN Office.

"Well once the AG report is tabled in Parliament, the Public Service Department will form an investigation committee headed by Integrity Unit. The members of committee selected from the ministry concerned (different department from the department been audited) as well as other ministries. They will revisit and do all the investigation process and prepared report" (OTHER ACTOR 6-INTERNAL AUDITOR).

"The investigation result will be reported to Chief Secretary General to the Government of Malaysia (KSN) within one month. The result in terms of latest action taken will be presented during the town hall session" (AUDITEE 9).

"Previously we didn't get much explanation on the issue. So, we will just pick up on the popular issues. Because this was what people wanted to know and we highlighted it. But lately when there is a town hall session, once AG report was out" (OTHER ACTOR 14-MEDIA). 
At the FUD level, they will also conduct follow-up on the punitive issues and prepare slides and a 'notification paper' (kertas makluman) which will be presented to committee members of JTLKAN, firstly the slides presentation during the meeting with six agencies. Again, it was interpreted that extensive follow-up initiative exists due to the nature of the issue as affirmed by the establishment of the meeting at this level. Audit issues with punitive elements are presented at six agencies to speed up the investigation and action process. This is to ensure that the next interaction at the JTLKAN level is smoother as acknowledged by some of the interviewees from among the auditors. Moreover, besides processing feedback answers from auditees in the AG's Dashboard, an additional record are also maintained by the FUD to update the status of follow-up on punitive issues.

"FUD has started to pick up the issue earlier and able to do further follow-up and prepare 'kertas makluman' for JTLKAN meeting" (AUDITOR 13).

"We will continuously monitor during the JTLKAN meeting and interact regularly with them for status updates. At FUD level some additional records are maintained to monitor the progress of punitive issues" (AUDITOR 1).

"AG report mostly triggered red flags that need to be further investigated. But beforehand we will thoroughly discuss all punitive issues presented to us by the FUD during the six agencies meeting and will decide agency that should take up the issues according to their jurisdiction and capacity. We will start the investigation and discuss further during the JTKLAN meeting" (REGULATOR 15).

In the field of performance auditing literature, Van Loocke and Put (2011, pg. 202-203) identified the approach of improving the impact of performance auditing is through follow-up initiatives that involve a network of actors. In line with the above finding, it can be argued that JTLKAN is evidence of how new strategy formed based on horizontal relationship which involved a network of relevant actors together with auditors and auditees deliberating on punitive audit issues. Decisions will be made in terms of further action; settlement and termination of an audit issue with evidence of further action such as investigation or sanction.

"JTLKAN is chaired by the Honourable Auditor-General and the members of JTLKAN are from various key enforcement as well as central agencies in Malaysia. They deliberate together on punitive audit issues which have elements of waste, extravagance, embezzlement and negligence" (AUDITOR 1).

"Enforcement agencies are part of the regular member of the Action Committee of Auditor-General's Report (JTLKAN) chaired by the Auditor-General...and JTLKAN is also a good strategy to follow-up on significant issues" (REGULATOR 15).

At this juncture, it can be summarised that, in governing the practice of followup, the interviewees described that it begins just after the initial audit team has sent in a performance auditing observation report to the auditees. The auditees 
need to prepare feedback and report to the auditors. Approximately, after a month, an exit conference will be executed at the auditees' organisation.

After the exit conference meeting, the finalisation of audit issues included in the AG's report will be performed after undergoing internal governing strategies through the interaction between auditors, and auditees. While, the six agencies meeting with regulators are carried out much earlier so as to make the enforcement agencies like MACC and Police to open an investigation paper for punitive audit issues. Once the AG's report is tabled in Parliament, more strategies are executed for following-up. Henceforth, many formal and informal interactions with many other actors were noted from interviewees' explanation and articulation. The formal interactions noted from the interviewees' articulation are inclusive of PAC Briefing Session, Auditor-General's (AG) Dashboard, Town hall session (however, this session with media is reported as been discontinued starting from year 2018) and Action Committee for Auditor-General's Report (JTLKAN).

Meanwhile, in between these main formal interactions, many more informal interactions strategies are executed as part of governance arrangements in the current follow-up practice. The execution of numbers of formal and informal interaction strategy through the formation of relationship in governing the practice has increased the involvement (in major events which are not limited to auditors and auditees) and interaction between different actors as summarised in Table 2.

While describing the governing strategy initiated and executed in the current follow-up practice, the interviewees indicated that formal and informal interactions are valid or held throughout follow-up on performance auditing issues. Based on the information and explanations given by the interviewees with regard to the follow-up strategies executed, this study summarises three phases for all the strategies which are, pre-tabling of AG's report, during the day of tabling AG's report and post-tabling of AG's report in Parliament. As such, followup effectiveness is assessed based on the extent of governance arrangement in practice and the types of network (see the next section).

In achieving the objective, the research began by investigating the participants' views on actors' role, their interdependence and perception; the extent of interactions and challenges encountered; institutional factors that influence their view and; the way they manage interaction and relationship with diverse actors. This provides evidence for the use of governance network theory as a valid theory to disclose an understanding of governance arrangements that take place during follow-up practice. This structural form of a network can either enable or constrain network outcomes (Cross, Borgatti, \& Parker, 2002) while the process leads the actors to being more committed to work with each other (Keast \& Mandell, 2013). By governing the practice of follow-up with various strategies as explained in this section, it contributes not only to the effectiveness of this practice, but further influences the formation of different types of networks.

\subsection{Network Types (Networking)}

Keast and Mandell (2013) assert that different relationship structures and processes are the results of different governing strategies. 
Table 2. Key Actors' Involvement in Events (Strategy)

\begin{tabular}{|c|c|c|}
\hline Events (Strategy) & Flow of Event & Actors Involved \\
\hline \multicolumn{3}{|c|}{ Pre-Tabling of AG Report } \\
\hline $\begin{array}{l}\text { Audit Observation } \\
\text { Report }\end{array}$ & $\begin{array}{l}\text { - Initial Audit Team Sends the report to } \\
\text { Auditee }\end{array}$ & Auditor - Auditee \\
\hline $\begin{array}{c}\text { Feedback } \\
\text { Coordinating Team }\end{array}$ & $\begin{array}{l}\text { - Auditee Coordinating Team coordinates } \\
\text { feedback answers and sends them to } \\
\text { Auditor }\end{array}$ & Auditee - Auditor \\
\hline $\begin{array}{c}\text { Internal } \\
\text { Investigation }\end{array}$ & $\begin{array}{l}\text { - Auditee forms Internal Investigation } \\
\text { Committee to investigate material issues } \\
\text { headed by the Internal Auditor }\end{array}$ & $\begin{array}{l}\text { Auditee - Other } \\
\text { Actors (Internal } \\
\text { Auditor) }\end{array}$ \\
\hline Exit Conference & $\begin{array}{l}\text { - Meeting held at auditees' office with } \\
\text { Auditees and Auditors. Permanent } \\
\text { Representatives from various agencies } \\
\text { are invited }\end{array}$ & $\begin{array}{l}\text { Auditors - Auditees- } \\
\text { Regulators-Other } \\
\text { Actors }\end{array}$ \\
\hline 6 Agencies Meeting & $\begin{array}{l}\text { - Presentation of Punitive Issues with the } \\
\text { elements of crime, corruption or } \\
\text { disciplinary to six Enforcement Agencies: } \\
\text { Public Service Department (PSD), Anti- } \\
\text { Corruption Agency (MACC); Royal } \\
\text { Malaysian Police (RMP); Attorney } \\
\text { General Chamber (AGC); Ministry of } \\
\text { Finance (MOF); and Economic Planning } \\
\text { Unit (EPU) }\end{array}$ & Auditor -Regulators \\
\hline \multicolumn{3}{|c|}{ During the Tabling of AG's Report } \\
\hline $\begin{array}{l}\text { AG Report Tabled } \\
\text { in Parliament } \\
\text { PAC Briefing } \\
\text { Session }\end{array}$ & $\begin{array}{l}\text { - Tabling of AG's report } \\
\text { - The AG briefs the PAC Members on } \\
\text { significant issues }\end{array}$ & $\begin{array}{c}\text { Auditors } \\
\text { Auditors - Regulators }\end{array}$ \\
\hline AG's Dashboard & - Dissemination of AG's report to Public & $\begin{array}{l}\text { Auditors-Auditees- } \\
\text { Regulators-Other } \\
\text { Actors }\end{array}$ \\
\hline $\begin{array}{l}\text { PAC Media } \\
\text { Conference }\end{array}$ & $\begin{array}{l}\text { - PAC Chairman will brief the media on } \\
\text { selected audit issues and ministries that } \\
\text { will be called for further inquiry }\end{array}$ & $\begin{array}{l}\text { Auditors-Regulators- } \\
\text { Other Actors }\end{array}$ \\
\hline \multicolumn{3}{|c|}{ Post-Tabling of AG's Report } \\
\hline Investigation & - Public Service Department formed & Auditee- Regulators- \\
\hline $\begin{array}{l}\text { Committee } \\
\text { Coordinated by PSD }\end{array}$ & $\begin{array}{l}\text { Investigation Committee within the } \\
\text { auditees' organisation, headed by } \\
\text { Integrity Unit }\end{array}$ & Other Actors \\
\hline Town Hall Session & $\begin{array}{l}\text { - Questions and answers through the } \\
\text { session with media are initiated by the } \\
\text { Office of Chief Secretary to the } \\
\text { Government of Malaysia (KSN) together } \\
\text { with the Public Service Department }\end{array}$ & $\begin{array}{l}\text { Auditors-Auditees- } \\
\text { Regulators-Other } \\
\text { Actors }\end{array}$ \\
\hline PAC Proceeding & $\begin{array}{l}\text { - Inquiry Session on selected issues by the } \\
\text { PAC }\end{array}$ & $\begin{array}{l}\text { Auditors-Auditees- } \\
\text { Regulators-Other } \\
\text { Actors }\end{array}$ \\
\hline JTLKAN & $\begin{array}{l}\text { - Full scale final meeting to discuss the } \\
\text { status and progress of punitive issues, } \\
\text { involves all the key actors }\end{array}$ & $\begin{array}{l}\text { Auditors-Auditees- } \\
\text { Regulators-Other } \\
\text { Actors }\end{array}$ \\
\hline
\end{tabular}


Thus, this study argues as evident in the interview data that, types of network formed (its structure and processes) as influenced by governance arrangements (strategy) may likely affect the operationalisation of follow-up and its effectiveness. This is because the structural form of a network can either enable or constrain network outcomes while the process leads the actors to being more committed to work with each other (Keast \& Mandell, 2013). By governing the practice of follow-up with various strategies, it influences the formation of different types of network. This study also examines the relationship between the types of network formed (its structure and processes) and their effects on followup effectiveness. The analyses of the interviews reveal that formation of network types is an important depiction of relationship that occurs due to the way the practice being governed nowadays.

"We need to coordinate the audit issues which come with the latest feedbacks... we coordinate those issues that we have to follow-up with other parties" (AUDITEE 7)

"Overall, we have ultimate role to coordinate all the follow-up matters at MNAD level. In fact, this division was formed solely to take care on follow-up matter. Not only, we need to coordinate internally but also externally" (AUDITOR 10)

The relationship that exists from coordination is later expanded to cooperation between auditors and external parties like regulators as explained by the interviewees. In the case of the follow-up process, the auditors said that engagement with regulators is needed. The relationship between the two groups of actors starts informally even before the AG's report is tabled in Parliament. The relationship continues after the tabling of the AG's report with more formal interactions.

"Basically, for any audit issue that has the elements of bribery, we need share the information with MACC, but we will make it secret" (AUDITOR 3)

"The auditors should inform us earlier as possible, so we can investigate before we lose the important evidence" (REGULATOR 14 - MACC)

"For audit issue that has criminal red flags indication, then we want the auditor to lodge a police report, and we will do the follow-up investigate" (REGULATOR 9POLICE)

A relationship that begins with the coordination and cooperation between the actors is further described by the interviewees on a wider scale. For example, interaction is not limited to auditors and auditees, given that the JTLKAN pooled various actors to deliberate and resolve audit issues. The relationship that exists and permits interaction between different actors is termed as collaboration. The following excerpts evince how the interviewees described such relationship.

"We communicate with many people during the JTLKAN...most issues deliberated and discussed here" (AUDITOR 14) 
"It's a big scale meeting, we have to face so many persons and the fact was we need to answer to their queries. So, we have to really get well prepared. But one thing good about it is, we can justify and discuss" (AUDITEE 8)

"I have experience attending the JTLKAN meeting as it involved the ministry I attached to" (OTHER ACTORS 6)

"We also have an important role, I would say. You know why, because follow-up means you need to take action. The auditors only audit and report. The police and MACC do investigation, but then they have to provide a valid case to bring it to the court trial. So, attention will come to us who need to update the progress any court case related to audit issue. So, JTLKAN is where we all can meet, discuss and update" (REGULATOR 12)

Evidence of collaboration involving audit institutions and other regulatory bodies has also been reviewed by the literature. For instance, Wilkins, Phillimore and Gilchrist (2017) report that interactions between various oversights bodies show the benefits of collaboration, leads to the enhancement of follow-up effectiveness. This collaboration according to the authors will not affect the independent level of the auditors but can help guide choices about the form and intensity of appropriate cooperation in making decisions. However, the authors advise stakeholders to be fully informed about the nature of oversight bodies, cooperation, benefits and limits exists in the collaboration so that the support and respect for audit institutions is maintained.

Indisputably, actors have numerous ways of operationalising their relationship. Although network types (networking) are not a direct concept of governance network theory as pointed out by Klijn and Koppenjan (2012), the authors claim, in governing social practice, the important aspect is how it is managed. Thus, network management is important because a number of interacting actors' networking occurs when a social practice is governed.

The interviewees stated that networking is crucial throughout the follow-up process. Therefore, types of network appear to be an important construct in executing follow-up practice. The research data indicates that follow-up practice is effective with key actors' participation in a network, interdependency between them in line with network perspective and how it is managed within the governance network theory. At this juncture, follow-up effectiveness is not represented by tangible outcomes of an action (numbers of issues that have been resolved, types of action, persons who have been charged, or follow-up report).

However, follow-up effectiveness can be perceived as the level of governing itself and the nature of networking existed between various actors. This means, effective follow-up practice is about governing and managing a relationship of governance actors who interact to solve a problem. Thus, exploring the effects of governance network on network types helps to depict how different network types influence follow-up effectiveness through the horizontal relationship. As governance actors coordinate, cooperate and collaborate throughout follow-up practice, it influences the level of horizontal relationship between governance arrangements and networking. For example, as the actors facilitate (coordinative), investigate together (cooperative), and deliberate and disseminate (collaborative) 
audit issues that need to be followed-up, this will allow the actors to advance on mutual understanding, interdependence, information sharing about follow-up matters, and the feeling of togetherness.

This strengthens the network performance of governance actors who engage and interact through the horizontal relationship. It is in line with the claims made by Irawan and Mills (2016) who asserted, considering various stakeholders' perspectives is important to look into the results of performance auditing activity in relation to follow-up on the issues emerge besides realising its impact and values.

In this context, governance networks point to the formation of a relationship which cannot be externally enforced but as a consequence of the interaction of various actors and an arrangement of governing (Kooiman, 1993). In summary, follow-up practice can be exercised in terms of strategy, structure and process as depicted through the theoretical framework in Figure 2. This study contributes to the understanding of follow-up effectiveness through the exploration between governance arrangements and networking as advocated by the governance network theory.

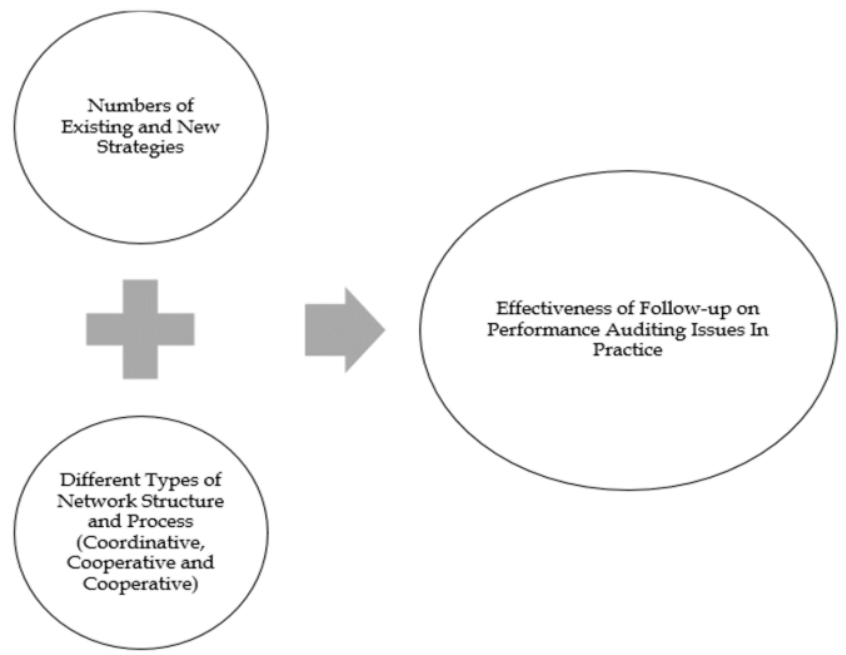

Figure 2. Theoretical Framework

\section{Conclusion}

The interaction with various actors is an important factor in determining followup practice to monitor the implementation of audit recommendations so as to address problems concerning the particular matter as highlighted in previous literature. This study provides a better understanding of follow-up effectiveness through the relationship between governance arrangements (strategy) and followup effectiveness besides network types or networking (structure and process).

This research provides evidence that it is important for the SAI to coordinate, cooperate and collaborate with relevant actors outside the organisation without compromising its independence. By revealing the importance of key actors' 
participations, this research has been able to corroborate the importance of regulators' participation in tackling audit issues with punitive elements such as crime, corruption and disciplinary. Continuous horizontal relationships with regulators are needed. This research has proven that such relationships would be better if they emerge much earlier. It indicates the need to go far beyond the SAI's legal audit mandate to audit and report. It is worth emphasising that the movements taken should be relative to the current follow-up practice and legitimate to amend relevant law or act. With such legitimation, auditees, regulators and other actors might regard auditors as the leading role that champions and triggers significant strategies, structures and processes that could enhance follow-up effectiveness (Irawan \& Mills, 2016).

This research has contributed theoretically and empirically. Nonetheless, it has several limitations. First, the researcher did not select performance auditing issues individually per se to see how each issue with punitive elements is addressed through a follow-up process. In order to perform in-depth research, researchers should select punitive issues and execute case study research. Since this research emphasised the nature and extent of various actors' interaction in follow-up practice, it could be argued that complete evidence on the settlement of certain complex audit issues may have been missed. Second, the ultimate limitation of purposive sampling adopted by this research is the impracticality to infer the results to the whole population. Thus, the findings may be limited in terms of generalisability. For instance, the sampling method may have introduced bias to the research results because the participants were not randomly selected. Thus, the conclusions of this research are limited to the governance actors who participated in this research. However, it is important to stress that generalisability is not the aim of this research because the samples were selected purposively to investigate the research purpose rather than to statically represent the population. Moreover, the value of qualitative research lies in the potential to generate rich data by exploring a range of perspectives and develop a holistic viewpoint (Cassell \& Symon, 2004) in the context within which the research phenomena are located, and for very detailed subject coverage (Ritchie, Lewis, Nicholls, \& Ormston, 2013).

This research used governance network theory as a framework of social constructivist institutionalism. Constructivism is a term frequently used interchangeably with interpretivism (Merriam, 2009). Interpretive research regards reality as socially constructed by multiple realities or interpretations for a single event and not based on sole observable reality. The reality explored in this paper provides rich possibilities for governance network literature in public sector auditing.

Research that focuses on the role of network has increased significantly in the field of public administration over the last two decades. However, little of the literature has ventured into the field of public sector auditing. This new research agenda has been approved by scholars to explore the potential of alternative forms of governance network arrangements, besides creating some conceptual and empirical challenges associated with the adaptation of network concept to the special needs of public sector performance auditing. Thus, this research has provided empirical evidence on the practice of follow-up on performance auditing issues in Malaysia. It thus offers an understanding of various actors' interaction 
by means of governing and networking that are perhaps highly effective. The expanded framework has been able to provide a richer description of the actual activities that surround follow-up practice, empirically.

On top of the above implication, this study is a preliminary attempt to explore the research area within the performance auditing literature by focusing on the theory which has gained little attention in performance auditing literature. This has opened up several fruitful avenues for future research. For instance, future research could also look into horizontal accountability relationships (Boven, 2010) to understand multiple accountabilities of different governance actors within networks (Romzek, 2015) in follow-up practice. By incorporating the theory, the research was able to answer how different actors assume, pose, understand and exercise the accountability entrusted to them. Consequently, the research was able to strengthen the claim that the networking in follow-up on performance auditing issue is not exercised only by a single actor's role responsibility, but collective roles of different actors.

The levels of accountability can be identified to depict who among the actors is supposed or assumed to have more accountability than other actors. The use of social behaviour and societal governance from a governance network perspective is important to understand further the underlying perspectives used by different actors while interacting through networks. Furthermore, conducting case studies approach would be useful to explore the types of networking practices that are most needed for network success. Moreover, further work can be done on the formation and validation of the attributes for assessing inter-organisational follow-up practice to include a greater variety of follow-up practice-related constructs. Research on the effectiveness of follow-up practice for three types of networking, namely coordinative, cooperative and collaborative networks, would be interesting to see how the forms of networking vary in terms of their influence and importance.

As a concluding remark, this research hopes that it has stimulated the need to transcend studies on follow-up practice rooted from performance auditing literature beyond the traditional New Public Management (NPM), Institutional Theory, and common conceptualisation of accountability. Berg (2004) and Berger and Luckmann (1966) argue that the value of social science research lies in its capability to provide different voices in the study of societal matters through various perspectives and lenses. In particular, Berger and Luckmann (1966) stress that social reality is human construction produced by social interaction. Meanwhile, social interaction relates to the belief that dynamic interaction between governance actors happens within the level of governance network in institutional domains (Lowndes \& Skelcher, 1998). Hence, in order to study the effectiveness of follow-up on performance auditing issues in practice, such theoretical diversity is required.

Irawan and Mills (2016) attest to the claim that considering various stakeholders' perspectives is important to look into the results of performance auditing activity in relation to follow-up on the issues emerge besides realising its impact and values. In this context, governance networks point to the formation of a relationship which cannot be externally enforced but as a consequence of the interaction of various actors and an arrangement of governing (Kooiman, 1993). 
In conclusion, this research has provided evidence that studying follow-up on performance audit issues in practice which encapsulates social behaviour, societal governance, and network perspective can produce intriguing results. This is important to provide a better understanding of the relationship between governance arrangements and networking in relation to the effectiveness of follow-up practice.

\section{References}

Ahmad, N., Othman, R., Othman, R., \& Jusoff, K. (2009). The effectiveness of internal audit in Malaysian public sector. Journal of Modern Accounting and Auditing, 5(9), 53-62. http:// repo.uum.edu.my/id/eprint/12749

Alwardat, Y.A. (2010). External auditors and clients: an investigation of perceptions of value for money (VfM) audit practices in the UK public sector (Doctoral dissertation, University of Westminster). https://doi:10.1111/ijau.12037

Alwardat, Y.A., Benamraoui, A., \& Rieple, A. (2015). Value for money and audit practice in the UK public sector. International Journal of Auditing, 19(3), 206-217. https://doi.org/10.1111/ijau.12037

Arthur, A., Rydland, L.T., \& Amundsen, K. (2012). The user perspective in performance auditing-A case study of Norway. American Journal of Evaluation, 33(1), 44-59. https://doi.org/10.1177/2F1098214011408283

Barrett, P. (2012). Performance auditing: Addressing real or perceived expectation gaps in the public sector. Public Money and Management, 32(2), $129-136$. https://doi.org/10.1111/ijau.12037

Bawole, J.N., \& Ibrahim, M. (2016). Contesting claims on measuring performance in the public sector using performance audits: Evidence from the literature. Public Organisation Review, 16(3), 285-299. http:// doi.org/10.1007/s11115-015-0312-4

Berg, B.L (2004). Qualitative research methods for the social sciences. Boston, MA: Pearson.

Berger, P.L., \& Luckmann, T. (1966). The social construction of reality. New York: Penguin Book.

Bhandari, (2014). Engaging Civil Service Organisations in SAI Audit. International Journal of Government Auditing, 41(2), 24-30. http:/ / www.intosaijournal.org/

Bovens, M. (2010). Two concepts of accountability: Accountability as a virtue and as a mechanism. West European Politics, 33(5), 946-967. https:// doi.org/10.4324/9781315879390-7

Braun, V., \& Clarke, V. (2006). Using thematic analysis in psychology. Qualitative Research in Psychology, 3(2), 77-101. https:/ / doi.org/ 10.1191/1478088706qp063oa

Braun, V., Clarke, V., Hayfield, N., \& Terry, G. (2019). Thematic analysis. Handbook of Research Methods in Health Social Sciences, 843-860. http://doi.org/10.1007/2F978-981-10-5251-4_103

Bringselius, L. (2014). The Dissemination of Results from Supreme Audit Institutions: Independent Partners with the Media? Financial Accountability and Management, 30, 75-94. https://doi.org/10.1111/faam.12028

Brooks, R.C., \& Pariser, D.B. (1995). Audit Recommendation Follow-Up Systems: A Survey of the States. Public Budgeting and Finance, 15(1), 72-83. https:// doi.org/10.1111/1540-5850.01032

Cassell, C., \& Symon, G. (2004). Essential guide to qualitative methods in organisational research. London, UK: Sage Publication Ltd.

Cresswell, T. (2014). Place: An introduction. West Sussex: John Wiley \& Sons.

Cross, R., Borgatti, S.P., \& Parker, A. (2002). Making invisible work visible: Using social network analysis to support strategic collaboration. California Management Review, 44(2), 25-46. https://doi.org/10.2307/2F41166121

Denzin, N.K., \& Lincoln, Y.S. (Eds.). (2011). The SAGE handbook of qualitative research. Sage.

Emerson, K., Nabatchi, T., \& Balogh, S. (2012). An integrative framework for collaborative governance. Journal of Public Administration Research and Theory, 22(1), 1-29. https:// doi.org/10.1093/jopart/mur011

Funnell, W., \& Wade, M. (2012). Negotiating the credibility of performance auditing. Critical Perspectives on Accounting, 23(6), 434-450. https:// doi.org/10.1016/j.cpa.2012.04.005 
Government Transformation Programmes Roadmap. (2010). Retrieved from, http://www.pmo.gov.my/

Hoque, Z., \& Pearson, D. (2018). Accountability reform, parliamentary oversight and the role of performance audit in Australia. In Podger, A., Su, T., Wanna, J, Chan, H.S., \& Niu, M. (Eds.), Value for Money Budget and Financial Management Reform in the People's Republic of China, Taiwan and Australia, (pp. 175). Acton, Australia: ANU Press. https://www.jstor.org/stable/j.ctt20krz22.15

Irawan, A.B., \& McIntyre-Mills, J. (2016). Application of Critical Systems Thinking to Performance Auditing Practice at the Indonesian Supreme Audit Institution: Issues and Challenges. Systems Research and Behavioural Science, 33(1), 24-44. https://doi.org/10.1002/ sres.2325

ISSAI 3000, (2004). Implementation guidelines for Performance Auditing, XVIII Congress of the International Congress of Supreme Audit Institutions, INTOSAI, Budapest.

Keast, R., \& Mandell, M. P. (2013). Network performance: a complex interplay of form and action. International Review of Public Administration, 18(2), 27-45. https:// doi.org/10.1080/12294659.2013.10805251

Keast, R., Brown, K., \& Mandell, M. (2007). Getting the right mix: Unpacking integration meanings and strategies. International Public Management Journal, 10(1), 9-33. https://doi.org/10.1080/10967490601185716

Kells, S., \& Hodge, G. (2011). Performance Auditing and Public Sector Innovation: Friends with Benefits or Strange Bedfellows? Asia Pacific Journal of Public Administration, 33(2), 163-184. https://doi.org/10.1080/23276665.2011.10779383

Klijn, E.H. (2008). Governance and governance networks in Europe: An assessment of ten years of research on the theme. Public Management Review, 10(4), 505-525. https:// doi.org/10.1080/14719030802263954

Klijn, E.H., \& Koppenjan, J. (2012). Governance network theory: past, present and future. Policy and Politics, 40(4), 587-606. https:// doi.org/10.1332/030557312X655431

Klijn, E.H., \& Koppenjan, J.F. (2000). Public management and policy networks: foundations of a network approach to governance. Public Management an International Journal of Research and Theory, 2(2), 135-158. https:// doi.org/10.1080/14719030000000007

Klijn, E.H., Steijn, B., \& Edelenbos, J. (2010). The impact of network management on outcomes in

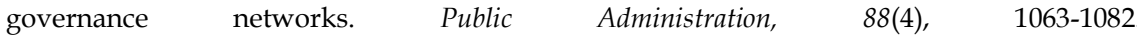
https://doi.org/10.1111/j.1467-9299.2010.01826.x

Kooiman, J. (2003). Governing as governance. Sage.

Kooiman, J. (Ed.). (1993). Modern governance: new government-society interactions. Sage.

Lonsdale, J. (2008). Balancing Independence and Responsiveness: A Practitioner Perspective on the Relationships Shaping Performance Audit. Evaluation, 14(2), 227-248. https://doi.org/10.1177/2F1356389007087541

Lowndes, V., \& Skelcher, C. (1998). The dynamics of multi-organisational partnerships: an analysis of changing modes of governance. Public Administration, 76(2), 313-333. https:// doi.org/10.1111/1467-9299.00103

McGee, R., \& Gaventa, J. (2011). Shifting power? Assessing the impact of transparency and accountability initiatives. IDS Working Papers, (383), 1-39. https://doi.org/10.1111/j.20400209.2011.00383_2.x

Merriam, S. B. (2009). Qualitative Research: a guide to design and interpretation. San Francisco: Jossey-Bass.

Mihret, D.G., \& Yismaw, A.W. (2007). Internal audit effectiveness: An Ethiopian public sector case $\begin{array}{llll}\text { study. Managerial Auditing } & \text { Journal, 22(5), }\end{array}$ https://doi.org/10.1108/02686900710750757

Morçöl, G. (2014). Complex governance networks: An assessment of the advances and prospects. Complexity, Governance and Networks, 1(1), 5-16. http:/ /dx.doi.org/10.7564/14-CGN5

Morin, D. (2014). Auditors General's impact on administrations: A Pan-Canadian study (20012011). Managerial Auditing Journal, 29(5), 395-426. https://doi.org/10.1108/MAJ-10-20130948/full/html

Morin, D. (2015). Parliamentarians' relations with the Auditor-General of Canada during Sheila Fraser's mandate. In Hoque, Z. (Eds.), Making Governments Accountable: The Role of Public 
Accounts Committees and National Audit Offices (pp. 59). New York: Routledge. https:// doi.org/10.4324/9781315768618-4

Mulgan, R. (2000). Accountability: An ever-expanding concept? Public Administration, 78, 555-573. https:// doi.org/10.1111/1467-9299.00218

Myers, M.D. (2013). Qualitative research in business and management. Sage.

Mzenzi, S.I., \& Gaspar, A.F. (2015). External auditing and accountability in the Tanzanian local government authorities. Managerial Auditing Journal, 30(6/7), 681-702. https://doi.org/10.1108/MAJ-04-2014-1028/full/html

Osborne, S.P. (2006). The new public governance?. Public Management Review, 8(3), 377-387. https://doi.org/10.1080/14719030600853022

Patton, M.Q. (2002). Two decades of developments in qualitative inquiry: A personal, experiential perspective. Qualitative Social Work, 1(3), 261-283. https://doi.org/10.1177/2F1473325002001003636

Pehe, J. (2012). Society: A Streetcar Named Graft. Transitions Online, (08/28).

Raudla, R., Taro, K., Agu, C., \& Douglas, J. W. (2015). The Impact of Performance Audit on Public Sector Organisations: The Case of Estonia. Public Organisation Review, 16, 217-233. https://doi.org/10.1007/s11115-015-0308-0

Reed, J., \& Cinq-Mars, J. (2014). How to Increase the Impact of Environmental Performance Audits?. International Journal of Government Auditing, 41(2), 17-23. https://doi.org/10.4324/9781351273480

Reichborn-Kjennerud, K. (2014). Auditee Strategies: An Investigation of Auditees' Reactions to the Norwegian State Audit Institution's Performance Audits. International Journal of Public Administration, 37, 685-694. https://doi.org/10.1080/01900692.2014.907309

Reichborn-kjennerud, K. (2015). Resistance to Control - Norwegian Ministries' and Agencies' Reactions to Performance Audit. Public Organisation Review, 15, 17-32. https://doi.org/10.1007/2Fs11115-013-0247-6

Reichborn-Kjennerud, K., \& Vabo, S. I. (2017). Performance audit as a contributor to change and improvement in public administration. Evaluation, 23(1), 6-23. https:// doi.org/10.1177/2F1356389016683871

Rhodes, R.A.W. (1996). The new governance: governing without government. Political Studies, 44(4), 652-667. https:// doi.org/10.1111/2Fj.1467-9248.1996.tb01747.x

Ritchie, J., Lewis, J., Nicholls, C.M., \& Ormston, R. (Eds.). (2013). Qualitative research practice: A guide for social science students and researchers. Sage.

Romzek, B.S. (2015). Living accountability: hot rhetoric, cool theory, and uneven practice. PS: Political Science and Politics, 48(1), 27-34. https://doi.org/10.1017/S1049096514001553

Siddiquee, N.A. (2010). Managing for results: lessons from public management reform in Malaysia. International Journal of Public Sector Management, 23(1), 38-53. https://doi.org/10.1108/09513551011012312

Siddiquee, N.A. (2014). The Government Transformation Programme in Malaysia: A Shining Example of Performance Management in the Public Sector. Asian Journal of Political Science, 22(3), 268-288. https:// doi.org/10.1080/02185377.2014.943256

Siddiquee, Noore Alam. (2013). The public bureaucracy: an analytical overview. In N. A. Siddiquee (Ed.), Public management and governance in Malaysia: trends and transformations. Abingdon: Routledge.

Sørensen, E., \& Torfing, J. (2005). The democratic anchorage of governance networks. Scandinavian Political Studies, 28(3), 195-218. https:// doi.org/10.1111/j.1467-9477.2005.00129.x

Sørensen, E., \& Torfing, J. (2007). Introduction governance network research: Towards a second generation. In Theories of democratic network governance (pp. 1-21). Palgrave Macmillan, London. https://doi.org/10.1057/9780230625006_1

Sørensen, E., \& Torfing, J. (2011). Enhancing collaborative innovation in the public sector. Administration and Society, 43(8), 842-868. https://doi.org/10.1177/2F0095399711418768

Stamati, T., Papadopoulos, T., \& Anagnostopoulos, D. (2015). Social media for openness and accountability in the public sector: Cases in the Greek context. Government Information Quarterly, 32(1), 12-29. https:// doi.org/10.1016/j.giq.2014.11.004 
Sullivan, H., Williams, P., Marchington, M., \& Knight, L. (2013). Collaborative futures: discursive realignments in austere times. Public Money and Management, 33(2), 123-130. https:// doi.org/10.1080/09540962.2013.763424

Torfing, J. (2005). Discourse theory: Achievements, arguments, and challenges. In Discourse theory in European politics. Palgrave Macmillan: UK, 1-32. https:/ /doi.org/10.1057/9780230523364_1

Torfing, J. (2006). Governance networks and their democratic anchorage. In New spaces of European governance (pp. 109-128). Facultas Verlags-und Buchhandels. https://doi.org/ 10801643509048745334\&hl

Van Loocke, E., \& Put, V. (2011). The impact of performance audits: A review of the existing evidence. Performance auditing: Contributing to accountability in democratic government, 175-208. https://doi.org/10.4337/9780857931801.00016

Vangen, S., Hayes, J.P., \& Cornforth, C. (2015). Governing cross-sector, inter-organisational $\begin{array}{llll}\text { collaborations. Public Management Review, 17(9), 1237-1260. } & \text {. }\end{array}$ https:// doi.org/10.1080/14719037.2014.903658

Wilkins, P., Phillimore, J., \& Gilchrist, D. (2017). Collaboration by the public sector: findings by watchdogs in Australia and New Zealand. Public Money and Management, 37(3), 217-224. https://doi.org/10.1080/09540962.2017.1282249

Xavier, J. A., Siddiquee, N. A., and Mohamed, M. Z. (2016). The Government Transformation Programme of Malaysia: a successful approach to public service reform. Public Money and Management, 36(2), 81-87. https://doi.org/10.1080/09540962.2016.1118927

Yang, K. (2012). Further understanding accountability in public organisations actionable knowledge and the structure-agency duality. Administration and Society, 44(3), 255-284. https://doi.org/10.1177/2F0095399711417699

Yapa, P.S. (2014). In whose interest? An examination of public sector governance in Brunei Darussalam. Critical Perspectives on Accounting, 25(8), 803-818. https://doi.org/10.1016/j.cpa.2014.03.003 